\title{
MEDICATION OR BAND-AID? REVISITING UNIVERSITY STUDENTS' READINESS FOR ONLINE EDUCATION
}

Dr. Murat CINAR

ORCID: 0000-0003-4012-4174

Borsa Istanbul Vocational and Technical Anatolian High School Republic of Turkey Ministry of National Education

Adana, TURKEY

Dr. Murat EKICI

ORCID: 0000-0003-2189-7294

Faculty of Education

Usak University

Usak, TURKEY

Dr. Omer DEMIR

ORCID: 0000-0002-4178-0221

Faculty of Education

Hakkari University

Hakkari, TURKEY

Received: 30/06/2020 Accepted: 22/09/2020

\section{ABSTRACT}

In the pandemic period we are currently in, online education has replaced face-to-face learning activities on a global scale. Institutions that pursue online education programs commonly assume that online learners are ready for this mode of learning. However, online education programs attract attention due to their remarkably high drop-out rates. This begs the question as to why some students are more able to benefit from online education, and demands to reveal the underlying reasons for such a situation. In this regard, the present study explores students' e-readiness for the changeover phase to online education, and how this differs in terms of a range of variables. 428 volunteer undergraduate students from 59 departments across 33 universities in Turkey were recruited to the study. The data collection tools consist of a personal information form and an online education readiness scale. The results indicate that university students' readiness levels for online education were above medium level of the scale. As for the factors which determine online education readiness, it was found that university students have a high level of internet self-efficacy, yet their motivation towards online education is considerably low. In addition, their online education readiness differs significantly in terms of personal computer ownership, internet connection at home, major, and daily internet usage duration, gender, and online education experience, whereas no statistically significant difference was identified in terms of grade year at the university. A significant interaction between gender and online education experience was ascertained as well.

Keywords: Distance education, online education, readiness, undergraduate students, COVID-19 pandemic.

\section{INTRODUCTION}

Online education is a form of education delivery in which learning activities are carried out mostly through technology with the educators and learners being in different locations. Distance education, the predecessor of online education, has a history of more than 200 years, starting with the postal service and continuing mostly through the use of web technologies at the present time. The realization of distance education via the web has led to the emergence of terminological inconsistencies, e.g. web-based learning/instruction, online 
education/learning, e-learning, virtual learning, and so on (Moore, Dickson-Deane, \& Galyen, 2011). Nevertheless, the concept referred to as distance education currently consists mostly of web-based learning activities. Consequently, these terms may be used interchangeably. Online education, which offers distance and lifelong learning by making use of Information and Communication Technology (ICT) opportunities, has become the new paradigm of education (Bilgic \& Tuzun, 2020; Chen, 2007; Mayer, 2017; Sun, Tsai, Finger, Chen, \& Yeh, 2008). In this study, the term 'online education' is preferred throughout because the educational activities in the Turkish higher education process during the pandemic-period were totally online.

Nowadays, commercial initiatives with regard to online education have gained momentum in line with increasingly competitive global market conditions (Chang, 2016). A great number of commercial and public institutions have started to provide their in-service training on the web. This is also the case for Turkey. As of 2020, more than half the 207 higher education institutions in Turkey contain a center for distance education. In many higher education institutions, common compulsory courses such as information technology, history, Turkish and foreign languages for freshmen are already taught fully online with mass-participation sessions. Therefore, to some extend, most university students have online education experience.

The underlying rationale of online education is to eliminate the physical obstacles in accessing education, such as time, place, cost, etc. This also constitutes an opportunity for testing pedagogical affordances of technology (Bates, 2005). Since the COVID-19 pandemic has recently made face-to-face interaction in education quite unfeasible, online education has been the only remedy for maintaining educational activities on a global scale. Based on the infographic information published by the United Nations Educational Scientific and Cultural Organization (UNESCO) (2020), the majority of students worldwide (at least 90\%) have had to interrupt their in-class learning. Due to the announcement of COVID-19 as a pandemic on 12 March 2020, and following the first cases, Turkey temporarily suspended school activities at all levels in line with risk assessments. In response to the request by the Turkish Council of Higher Education, universities with essential infrastructure started to conduct their education activities entirely through the Internet as of 23 March 2020. From this date, the national open courseware platform also made a wide range of learning resources available to students in order to compensate for learning shortcomings, even if not for all courses. Beyond the inevitable transition to online education, this process brings to mind once again the factors that drive a successful online education process. Whether with regard to face-to-face or distance learning activities, the classical instructional design process is realized following the determination of needs. The design of online education in the pandemic period has been a sudden transformation initiative that bypasses most of the conventional instructional design stages. Rather, the transition to online education seems to be closely related to a rapid instructional design process involving carrying out instructional stages with minimum planning from a pragmatic perspective (Batane, 2010). However, access to technologies does not guarantee their effective use. Therefore, a rapid transition to online education is likely to cause pedagogical and technological tensions. Online education includes a number of components that are also included in face-to-face instruction, but not limited to this. It also brings a range of new challenges, as well as opportunities, inherent in the online environment (Boling, Hough, Krinsky, Saleem, \& Stevens, 2012; Tuzun \& Cinar, 2016).

The number of students enrolled in online higher education programs is expected to rise in the future, especially with the driving force of online education awareness that possibly occurred throughout the community during the pandemic period. However, future demand for online education is largely shaped by pioneering experiences. From an evolutionary perspective, exposing students to online learning environments and waiting for them to succeed does not go beyond causing them to undergo natural selection. A body of research on how online learning can be more effective points out learner characteristics and readiness levels. Readiness is one of the most prominent components directly influencing learning outcomes in online education (Joosten \& Cusatis, 2020). The current study explores students' preparedness for online education, and how this differs in terms of learner characteristics. The reason for the study being conducted with regard to undergraduate students is that higher education contains the most online learning initiatives among all education levels. In addition, higher education instructional activities were carried out solely online during the pandemic period, unlike with regard to the K-12 level, where online education applications were supported with asynchronous TV broadcasts. 


\section{ONLINE EDUCATION READINESS}

The research initiatives on online education readiness can be characterized in terms of sectoral domains (educational and non-educational institutions such as public and private/commercial organizations), stakeholders (students, faculty/teachers, institutions, parents), school or grade level (pre K to K-12, undergraduate, post-graduate education), disciplines/major areas, contexts (theoretical/conceptual and practical). Here, the studies carried out specifically in the context of undergraduate education were examined. In literature, online education readiness was studied at the undergraduate level under a wide variety of theoretical components (See. Table 1).

Table 1. Examination of survey studies in the literature with regard to undergraduate students' online education readiness in terms of theoretical components

\begin{tabular}{ll}
\hline Authors & Online education readiness factors \\
\hline Hung, Chou, Chen, and Own (2010) & $\begin{array}{l}\text { Self-directed learning, motivation, computer and internet self- } \\
\text { efficacy, learner control, online communication self-efficacy }\end{array}$ \\
\hline Unal, Alir, and Soydal (2014) & $\begin{array}{l}\text { Technology availability, technology use, self-confidence, } \\
\text { acceptance, training needs }\end{array}$ \\
\hline Smith, Murphy, and Mahoney (2003) & $\begin{array}{l}\text { Comfort, self-management } \\
\text { Tubaishat and Lansari (2011) }\end{array}$ \\
\hline $\begin{array}{l}\text { ICT infrastructure, Internet use, technical skills (computer use } \\
\text { skills), confidence, communication mode preference, perception } \\
\text { towards e-learning (perceived learning outcomes) }\end{array}$ \\
$\begin{array}{l}\text { Confidence in skills, general beliefs towards e-learning, Self- } \\
\text { direction and initiative (self-management), willingness to interact } \\
\text { with others }\end{array}$ \\
\hline $\begin{array}{l}\text { Dray, Lowenthal, Miszkiewicz, Ruiz-Primo, and } \\
\text { Marczynski (2011) }\end{array}$ & $\begin{array}{l}\text {-Learner characteristics (belief in their ability, responsibility in } \\
\text { orientation and management, behavior regulation for goal } \\
\text { attainment) } \\
\text {-Technology capabilities (basic technology skills/material access } \\
\text { to technology, nature/frequency of technology use) }\end{array}$ \\
\hline $\begin{array}{l}\text { Online work skills (proficiency in access and use of technology), } \\
\text { social technology familiarity, organization skills (approaches to } \\
\text { task in organized and goal-oriented manner), online learning } \\
\text { efficacy (efficacy beliefs), self-directedness, socialization }\end{array}$ \\
\hline $\begin{array}{l}\text { Computer self-efficacy, internet self-efficacy, online } \\
\text { communication self-efficacy, self-directed learning, learner } \\
\text { control, motivation towards e-learning }\end{array}$ \\
\hline
\end{tabular}

There are also studies in the literature that approach online education from a more holistic perspective (Darab \& Montazer, 2011; Demir \& Yurdugul, 2015; Omoda-Onyait \& Lubega, 2011). The technology acceptance model (Davis, 1989) formed the basis for several studies that provide a model or systemic point of view with regard to online education preparation (Akaslan \& Law, 2011a, 2011b; Asaari \& Karia, 2005). Asaari and Karia (2005) suggested that ICT availability (PC ownership and Internet access) affect users' perceptions of usefulness and ease of use with regard to online education systems, and consequently their online education readiness levels. Akaslan and Law (2011a, 2011b) stated that the preparation for online education should be measured in three-stages - readiness, acceptance and training. The components associated with the readiness stage are technology, people, content, and institution. The human factor includes experience, confidence, and attitude in addition to traditional skills. The acceptance stage is based on the technology acceptance model. The last stage is the development of the student, teacher and personnel training, and the enhancement of facilities. It can be said that the competencies depicted in the model with regard to the human factor are narrow in scope. The conceptual model rather resembles an implementation plan overall. In many studies, this framework was used to evaluate the readiness of students as well as that of teachers (Akaslan \& Law, 2011a, 2011b; Soydal, Alir, \& Unal, 2011; Unal et al., 2014). 
As can also be seen in Table 1, there is no consensus in the literature with regard to online education components (Demir \& Yurdugul, 2015). The existing instruments are commonly based on learner characteristics, ICT access, and technology self-efficacy (Dray et al., 2011). A considerable number of the available online education readiness tools are based on pioneering research such as that of McVay (2000) and Hung et al. (2010). Considering the evolving nature of online education technologies and learning environments, it should be noted that a theoretical framework dating back to the 2000s may be insufficient to portray today's online education conditions. In this study, the instrument developed by Yurdugul and Demir (2017) based on the work of Hung et al. (2010), was used to determine the online education readiness of the students. Unlike Hung et al. (2010), Yurdugul and Demir (2017) considered the computer and internet self-efficacy separately, and consequently proposed a six-factor scale, involving motivation towards online education, learner control, self-directed learning, online communication self-efficacy, Internet usage self-efficacy, and ICT usage self-efficacy. The researchers revealed second-order patterns among the factors by drawing on the inter-factor relationships. According to hierarchical confirmatory factor analysis, motivation, learner control, and self-directed learning factors are grouped under the autonomous learning construct. On the other hand, computer, internet, and online communication self-efficacies are collected under the technology usage self-efficacy construct.

Online education is a self-initiative effort and online learners attend and progress their effort in pursuit of self-determined learning goals. This requires learner motivation in order to maintain learning efforts in the online environment. Both self-directed learning and learner control represent the metacognitive dimension of online education. Online education competence is closely related to self-directed and independent learning skills (Zhu, Bonk, \& Doo, 2020). In terms of the most inclusive definition, self-directed learning is the ability to learn with little or no dependence on others (Demir \& Yurdugul, 2013; Garrison, 1997; Knowles, 1975). In traditional instructional settings, the control and management of learning tasks is often exogenous. Online education promotes student autonomy. This aspect passes responsibility and control of learning from teachers to students. Briefly, it is reasonable to suggest that all these skills (also called autonomous learning) can be used as important indicators for predicting online education readiness.

Technology usage competencies as well as learner characteristics are frequently emphasized in online education (Dray et al., 2011). Today, digital inequality has shifted to differences in the use of technology rather than differences in accessing it. Computer use and activities in online environments for learning purposes require different competencies. In this sense, learners should both use computer technologies and direct online activities appropriately to ensure fruitful online educational experiences. Regardless of the delivery modality (face-to-face or distance), social interactions contribute to human thinking/intellectual development in a unique way, and enable learners to establish common knowledge in educational settings (Vygotsky, 1978). The dialogues of learners with their peers and with teachers pave the way not only for their learning, but also for self-monitoring and regulation processes (Mercer \& Howe, 2012). In order to perform their online education tasks, it is a prerequisite skill set for learners to have confidence in using computer and online technologies, being able to express themselves and to interact with others in the online environment (Joosten \& Cusatis, 2020). Therefore, the fact that learners benefit from online education processes does not solely depend on computer and internet competencies, but also on online communication skills.

\section{READINESS AND ONLINE EDUCATION: GAPS IN THE LITERATURE}

The demand for wholly online education programs, as well as the number and variety of programs delivered through online education, is gradually increasing worldwide. On the other hand, despite the gradually expanding proportion of online education in the education system, high dropout rates following the first experiences deserve more focus on the learner perspective. This begs the question as to why some students are more prone to benefit from online education and requires researchers to reveal the underlying reasons for such a situation. On the other hand, learner readiness is not adequately addressed in studies conducted with regard to online education, which is more common in higher education settings than in K-12 ones (Darab \& Montazer, 2011; Ilgaz \& Gulbahar, 2015; Parkes, Stein, \& Reading, 2015). Online education provides learners with greater flexibility when it comes to organizing and managing their learning activities (e.g. assignments, working on course content) beyond simply choosing the learning time and place. Institutions 
that pursue online education programs generally assume that online learners are ready for this new type of learning. Unlike face-to-face education, online education entails new competences in addition to offering new opportunities and revealing limitations. In the literature, some studies are based on a mere comparison of distance/blended learning education with face-to-face equivalents in higher education (McCutcheon, Lohan, Traynor, \& Martin, 2015; Simonson, Schlosser, \& Orellana, 2011). In addition, most studies on online education practices generally focus on learning outcomes, mostly in the form of achievement scores that are commonly obtained from tests involving closed and multiple-choice questions (Stodberg, 2012). The evaluation of online education initiatives without considering learner characteristics and preparedness does not go beyond simple tunnel vision. Therefore, it is crucial to determine the online education readiness levels of learners before implementing online education programs. In addition, the determination of other external variables that have an impact on the online education readiness of students can also guide preparatory training with regard to online education. However, when online education readiness studies are examined, it can be seen that the research efforts are generally conducted in the context of a specific higher education program or institution. Moreover, the participants are mostly teacher candidates. Thus, there is a lack of studies that represent more diverse participants. In this regard, the present study examines the online education readiness status of students from a wide variety of departments and universities. To this end, the following research questions were formulated.

1. What are the factor-wise online education readiness levels of undergraduate students?

2. Do online education readiness levels of university students differ by (a) personal computer ownership, (b) internet access at home, (c) grade year at the university, (d) major, (e) daily internet usage, (f) gender and online education experience?

\section{METHODOLOGY}

This is a survey study. It is the quantitative research procedure used to describe tendencies or patterns in attitudes, intentions, opinions, behavior patterns, or characteristics of a particular or target population (Creswell, 2012). This study took a snapshot of university students' online education readiness levels shortly before the compulsory transition of residential courses to online.

\section{Participants}

428 volunteer university students from 59 different departments of 33 universities in Turkey were recruited to the study based on the convenience sampling method. As a result of the closure of universities due to the COVID-19 pandemic, it was not possible to use a random sampling method. $37.6 \%$ of the participants were male $(\mathrm{n}=161)$ and $62.4 \%$ were female $(\mathrm{n}=267)$. The research sample mainly comprises students at the $4^{\text {th }}$ grade level and above $(40.7 \%, \mathrm{n}=174)$. Most of the participants are from non-computing majors $(87.4 \%, \mathrm{n}=374)$. Nearly two out of three of the participants $(63.3 \%, \mathrm{n}=271)$ had personal computers. In addition, $76.9 \%(\mathrm{n}=329)$ had internet access at their home. Approximately half of them use Internet between $4-7$ hours $(48.8 \%, \mathrm{n}=209)$. Half of the participants $(50 \%, \mathrm{n}=214)$ had not taken any online courses before. Further details in relation to participants' characteristics are also given in Table 2.

Table 2. Participants' characteristics regarding independent variables of the study

\begin{tabular}{cccc}
\hline Variable & Category & Frequency $(\boldsymbol{f})$ & Percentage (\%) \\
\hline Gender & Male & 161 & 37.6 \\
& Female & 267 & 62.4 \\
\hline Grade level & 1 & 46 & 10.7 \\
& 2 & 110 & 25.7 \\
& 3 & 98 & 22.9 \\
& 4 and above & 174 & 40.7 \\
\hline
\end{tabular}




\begin{tabular}{cccc}
\hline Major & Computing & 53 & 12.4 \\
& Non-computing & 374 & 87.4 \\
& N/A & 1 & 0.2 \\
\hline $\begin{array}{c}\text { Personal computer } \\
\text { ownership }\end{array}$ & Yes & 271 & 63.3 \\
\hline Internet access at home & Yes & 157 & 36.7 \\
\hline Daily Internet usage & No & 329 & 76.9 \\
& $1-3$ hours & 99 & 23.1 \\
\hline Ons than 1 hour & $4-5$ hours & 42 & 9.8 \\
experience & $6-7$ hours & 89 & 20.8 \\
& 8 hours and above & 107 & 25.0 \\
& No & 102 & 23.8 \\
\hline & Ligh (More than 3 courses) & 88 & 20.5 \\
\hline
\end{tabular}

\section{Data Collection Tools}

Two data collection tools were used in this study. The first was a personal information form. It included eight pieces of information - gender, grade, department, university, the number of online courses taken, the ownership of a personal computer, the availability of an internet connection at home and lastly duration of daily internet usage average. The second tool was an online education readiness scale for university students developed by Yurdugul and Demir (2017). This scale is composed of 33 items and six factors. These factors are computer self-efficacy (five items), internet self-efficacy (four items), online communication self-efficacy (five items), self-directed learning (eight items), learner control (four items) and lastly motivation towards online education (seven items). Cronbach alpha reliability coefficients of the factors of the original scale were reported as $.84, .85, .84, .88, .91, .95$, respectively. The overall reliability of the online education readiness scale was reported as .93 . In the current study, Cronbach alpha reliability coefficients of the factors were recalculated as .934, .904, .915, .937, .952 and .956 , respectively, while the reliability of the overall scale was found out to be .970 . It is a 7-likert type scale with alternative 1 corresponding to "it is not suitable for me at all" and 7 to "it is totally suitable for me". The higher the scores the university students get from the scale of online education readiness, the more they are ready for online education.

\section{Data Collection Process}

All necessary ethical permissions for the study were obtained from Usak University Ethics Commission before the data collection phase. The online education readiness scale and personal information form were combined prior to data collection, and then administered to participants as a uniform instrument through an online link. The online link was distributed through the social media platforms; mainly online communities (sites, groups, etc.) of which undergraduate students were members. The data were collected in an early phase of compulsory transition to online education at the nation-wide level. The link was in circulation on the web for nearly two weeks (12 days). As of mid-April, the data collection process was terminated as the researchers were of the opinion that the data were saturated enough.

\section{Data Analysis}

First, five observations were discarded from the dataset owing to inappropriateness for the study. And then, linear interpolation method was used to replace missing values. After that, factor scores were obtained by averaging relevant items. The online education readiness levels of the students were then analyzed in terms 
of subscales and overall scale scores by using item mean and standard deviation values. The effects of the independent variables, which are ICT access, school year, major, daily Internet usage, gender and online education experiences on the overall online education readiness level were analyzed using independent samples t-test or variance analysis. The online education readiness was accepted as a dependent variable. With respect to the assumptions, the data were accepted as normally distributed as per central limit theorem (Kwak \& Kim, 2017). Following variance analysis, the Bonferroni or the Games-Howell post-hoc comparisons depending on the result of Levene's test was used to determine the differences within groups. Cohen's $\mathrm{d}$ values for independent samples t-test and eta-square $\left(\eta^{2}\right)$ values for ANOVA were used for reporting effect sizes to interpret pratical meaning of statistically significant results. The Cohen's $d$ values were calculated based on mean, standard deviation and sample size (Cohen, 1988). The statistical significance threshold value was accepted as .05 .

\section{FINDINGS}

The findings are presented in order of the research questions (RQ). Factor-wise findings could not be reported due to word limitations except for the first research question.

\section{Online Education Readiness Levels of University Students (RQ 1)}

The findings in relation to the first research questions are given in Figure 1.

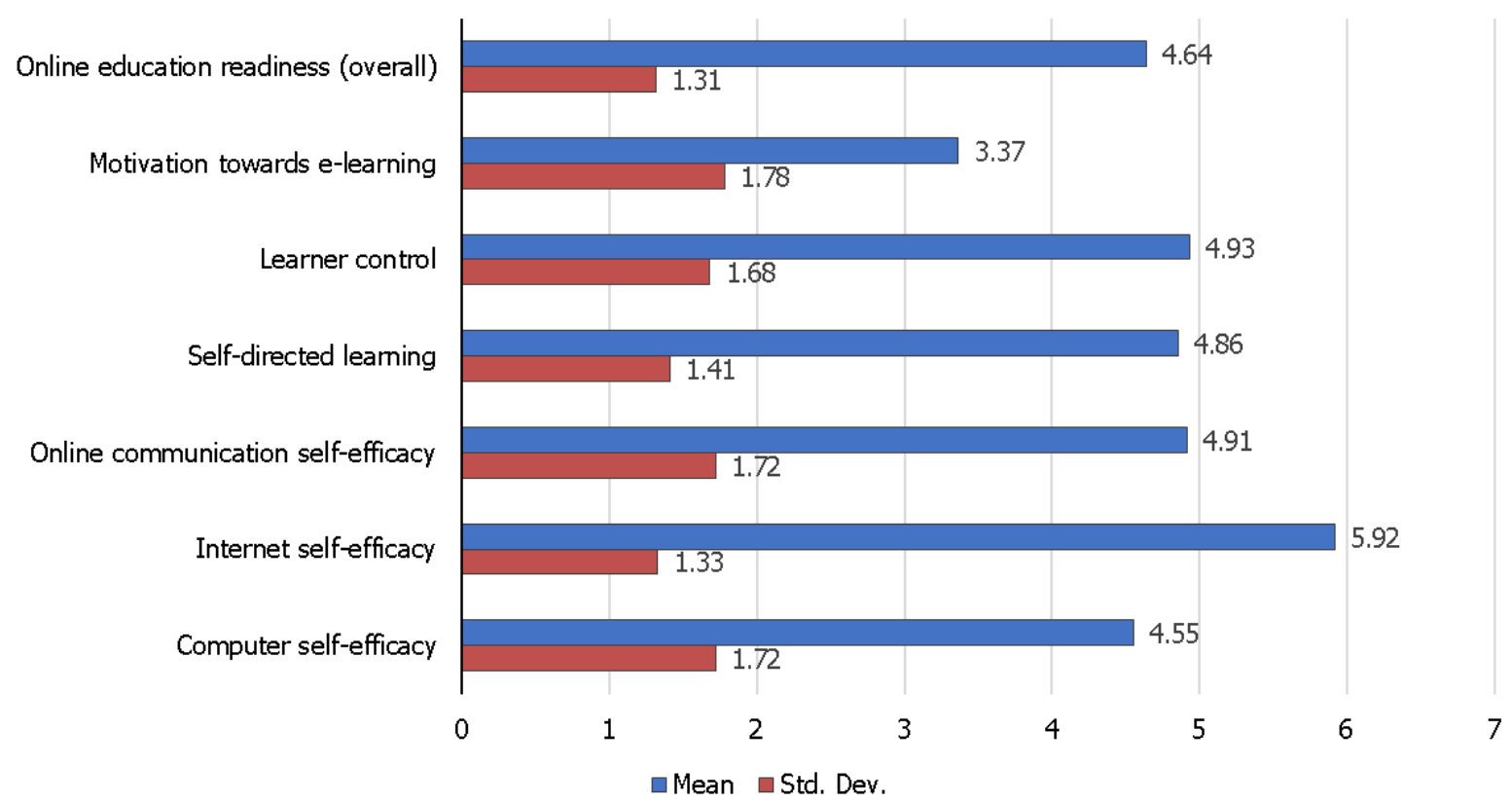

Figure 1. The status of participants' factor-wise online education readiness levels

As seen in Figure 1, students' motivation towards online education $(\mathrm{M}=3.37, \mathrm{SD}=1.78)$ is comparatively low, whereas their internet self-efficacy $(\mathrm{M}=5.92, \mathrm{SD}=1.33)$ is comparatively high. The means of other factors range between 4.55 and 4.93. Overall online education readiness is above the mid-level of the scale $(\mathrm{M}=4.64, \mathrm{SD}=1.31)$. 


\section{Students' Online Education Readiness Levels According to Their Characteristics (RQ 2)}

The results of research question $2 \mathrm{a}, 2 \mathrm{~b}$, and $2 \mathrm{~d}$ are summarized in Table 3 .

Table 3. Independent samples t-test results by personal computer ownership, internet access at home, and major

\begin{tabular}{|c|c|c|c|c|c|c|c|c|c|c|}
\hline $\begin{array}{l}\text { Research } \\
\text { question }\end{array}$ & Variable & Group & $\mathbf{n}$ & M & SD & $\mathbf{t}$ & df & $\mathbf{p}$ & Cohen's d & $\begin{array}{l}\text { aEffect size } \\
\text { Interpretation }\end{array}$ \\
\hline \multirow{2}{*}{$2 a$} & \multirow{2}{*}{$\begin{array}{l}\text { Personal } \\
\text { computer } \\
\text { ownership }\end{array}$} & Yes & 271 & 5.01 & 1.13 & \multirow{2}{*}{7.66} & \multirow{2}{*}{276.82} & \multirow{2}{*}{$.000^{* * * *}$} & \multirow{2}{*}{.810} & \multirow{2}{*}{ Large } \\
\hline & & No & 157 & 4.01 & 1.38 & & & & & \\
\hline \multirow{2}{*}{$2 b$} & \multirow{2}{*}{$\begin{array}{l}\text { Internet access } \\
\text { at home }\end{array}$} & Yes & 329 & 4.88 & 1.18 & \multirow{2}{*}{6.69} & \multirow{2}{*}{141.29} & \multirow{2}{*}{$.000^{* * *}$} & \multirow{2}{*}{.846} & \multirow{2}{*}{ Large } \\
\hline & & No & 99 & 3.84 & 1.42 & & & & & \\
\hline \multirow[b]{2}{*}{$2 d$} & \multirow[b]{2}{*}{ Major } & Computing & 53 & 5.69 & .77 & \multirow[b]{2}{*}{9.55} & \multirow[b]{2}{*}{101.60} & \multirow[b]{2}{*}{$.000^{* * *}$} & \multirow[b]{2}{*}{.952} & \multirow[b]{2}{*}{ Large } \\
\hline & & $\begin{array}{l}\text { Non- } \\
\text { computing }\end{array}$ & 374 & 4.49 & 1.31 & & & & & \\
\hline
\end{tabular}

aInterpreted in accordance with the Cohen's (1988) suggestion. *** Significant at the level of .001.

Students' Online Education Readiness Levels According to Personal Computer Ownership (RQ 2a)

An independent samples t-test was conducted to evaluate the effect of personal computer ownership on online education readiness. There was a statistically significant difference in comparisons between owner and non-owner students $(\mathrm{t}(276.82)=7.66, \mathrm{p}=.000, d=.810)$. Owners had higher scores $(\mathrm{M}=5.01, \mathrm{SD}=1.13)$ than non-owners $(\mathrm{M}=4.01, \mathrm{SD}=1.38)$.

\section{Students' Online Education Readiness Levels According to Internet Access at Home (RQ 2b)}

An independent samples t-test was conducted to evaluate the effect of having internet access at home on online education readiness and there was a statistically significant difference in comparisons between students with access and without access $(\mathrm{t}(141.29)=6.69, \mathrm{p}=.000, d=.846)$. Students with internet access had higher scores $(M=4.88, S D=1.18)$ than those without internet access $(M=3.84, S D=1.42)$.

Students' Online Education Readiness Levels According to Grade Year at the University (RQ 2c)

A one-way analysis of variance showed that the effect of grade year at the university on online education readiness was not statistically significant $(\mathrm{F}(3,424)=1.489, \mathrm{p}=.217)$.

\section{Students' Online Education Readiness Levels According to Major (RQ 2d)}

An independent samples t-test was conducted to evaluate the effect of major on online education readiness. The results showed that there was a statistically significant difference in comparisons between computing and non-computing major students $(\mathrm{t}(101.60)=9.55, \mathrm{p}=.000, d=.952)$. Students with computing majors had higher scores $(M=5.69, S D=.77)$ than non-computing ones $(M=4.49, S D=1.31)$.

\section{Students' Online Education Readiness Levels Accorting to Daily Internet Usage Level (RQ 2e)}

An analysis of variance showed that the effect of the amount of time spent online on online education readiness was statistically significant $(\mathrm{F}(4,423)=25.62, \mathrm{p}=.000)$. Post-hoc comparisons using the Games- 
Howell test indicated that the mean score of less than one hour users group $(\mathrm{M}=3.12, \mathrm{SD}=1.44)$ was significantly lower than that of the others. The mean score of $1-3$ hours users group $(\mathrm{M}=4.32, \mathrm{SD}=1.36)$ was significantly lower than that of both 6-7 hours group $(\mathrm{M}=4.96, \mathrm{SD}=1.13)$ and the 8 hours and above group $(M=5.19, S D=1.02)$. Lastly, the mean score of $4-5$ hours group $(M=4.75, S D=1.10)$ was found significantly lower than that of the 8 hours and above group. Post-hoc comparisons are given in Table 4.

Table 4. Post-hoc comparisons using the Games-Howell test of time spent online by students

\begin{tabular}{|c|c|c|c|c|c|c|c|c|c|c|c|}
\hline & \multicolumn{2}{|c|}{$\begin{array}{c}<1 \text { hour }(1) \\
n=42\end{array}$} & \multicolumn{2}{|c|}{$\begin{array}{c}1-3 \text { hours (2) } \\
n=89\end{array}$} & \multicolumn{2}{|c|}{$\begin{array}{c}4-5 \text { hours (3) } \\
n=107\end{array}$} & \multicolumn{2}{|c|}{$\begin{array}{c}\text { 6-7 hours (4) } \\
n=102\end{array}$} & \multicolumn{2}{|c|}{$\begin{array}{c}\geq 8 \text { hours (5) } \\
n=88\end{array}$} & \multirow[b]{2}{*}{ Post-hoc } \\
\hline & $M$ & SD & $M$ & SD & $M$ & SD & $M$ & SD & $M$ & SD & \\
\hline $\begin{array}{l}\text { Online education } \\
\text { readiness }\end{array}$ & 3.12 & 1.44 & 4.32 & 1.36 & 4.75 & 1.10 & 4.96 & 1.13 & 5.19 & 1.02 & $\begin{array}{c}1<2,3,4,5 \\
2<4,5 \\
3<5\end{array}$ \\
\hline
\end{tabular}

\section{Students' Online Education Readiness Levels According to Gender and Online Education Experience (RQ 2f)}

A two-way ANOVA was conducted on a sample of 428 university students to examine the main interaction effects of gender and online education experience as well as their interaction effects on online education readiness. The main effect of gender on online education readiness was statistically significant $(\mathrm{F}(1,422)$ $\left.=41.368, \mathrm{p}=.000, \eta^{2}=.089\right)$. Males had higher scores $(\mathrm{M}=5.31, \mathrm{SD}=1.48)$ than females $(\mathrm{M}=4.36$, $\mathrm{SD}=1.47)$ had. The main effect of online education experience on online education readiness yielded a statistically significant result $\left(\mathrm{F}(2,422)=4.147, \mathrm{p}=.016, \eta^{2}=.019\right)$. Post-hoc results using the Bonferroni test showed that university students with high online education experience $(M=5.14, S D=1.30)$ is readier for online education than those with no experience $(M=4.59, S D=1.27)$. There was a statistically significant interaction between the effects of gender and online education experience $\left(F(2,422)=5.064, p=.007, \eta^{2}\right.$ $=.023)$. Simple main effects analysis revealed that males were significantly readier for online education than females when they have no $(\mathrm{p}=.010)$, low $(\mathrm{p}=.002)$, and high online education experience $(\mathrm{p}=.000)$.

\section{DISCUSSION}

In the present study, undergraduate students were found to be above-average level ready for online education in terms of the overall scale $(\mathrm{M}=4.64)$. As far as factors are concerned, internet usage self-efficacy is the highest $(M=5.92)$, while motivation towards online education is the lowest $(M=3.37)$. Nevertheless, the online education readiness levels noted in the current study is quite low compared to that in Yurdugul and Demir's (2017) study, who found overall online education readiness, internet usage self-efficacy, and motivation towards online education means as being 5.56, 6.33, and 4.59, respectively. This indicates that there is almost a one-point difference in overall online education readiness, and more than a onepoint difference in terms of the motivation factor. Yet, their findings as to which factor of online education readiness is the highest and the lowest concur with the present study. In support of these, the findings of Coskun, Ozeke, Budakoglu, and Kula (2018) suggested internet self-efficacy as the highest $(M=5.84)$, while motivation towards online education as the lowest factor $(M=4.11)$. This pattern did not change in the study by Yilmaz, Sezer, and Yurdugul (2019). They reported overall online education readiness as being 5.20 , which is slightly higher than the result obtained in the current study. To sum up, regarding Yurdugul and Demir's (2017) study, the difference might be attributed to the fact that the current study collected data from various universities irrespective of their faculty and department, whereas Yurdugul and Demir (2017) collected data only from pre-service teachers at a university. As for the internet self-efficacy factor, it was found in the current study that the internet penetration rate among university students in Turkey (76.9\%) is relatively high. Indeed, even if students do not have access to the internet at home, they can still connect 
to it at universities or through mobile devices. This prevalence of internet access appears to have promoted university students' internet self-efficacy factor in terms of online education readiness. Another interesting finding of the present study, which agrees with the literature, is the critical low level of motivation towards online education. This lowness might stem from the lack of hardware as well as interaction during online courses. In addition, the use of inappropriate instructional methods by faculty members when it comes to online education, which can lead to adverse online education experiences for undergraduate students, is fairly likely to cause this low level. Motivation arises from a context that involves versatile interaction between learners and online education environments, rather than intrinsic characteristics (Hartnett, St George, \& Dron, 2011). Therefore, effective and well-planned online education processes enhance learner motivation (Law, Lee, \& Yu, 2010). It is also possible that a sense of isolation deriving from the pandemicrelated lockdown might have contributed to the decrease in motivation towards online education.

In this study, computer ownership was revealed to be a variable that affect online education readiness. This finding is supported by Yilmaz et al. (2019) who revealed that personal computer ownership positively affects online education readiness levels. Kabatas's (2019) findings also concur with this paper. In addition, the study conducted with tourism students by Pala (2018) echoed the finding of the current study. On the other hand, Basol, Cigdem, and Unver (2018) came to the conclusion that computer ownership does not predict online education readiness. As for the effect of internet access at home on online education readiness, it was revealed in the current study that university students having internet access at home are readier than those not having such access. A study carried out by Yilmaz et al. (2019) might support the finding of this study. They reported that university students having "a smart phone with internet connection" are readier for online education. On the other hand, it was found by Pala (2018) that having access to the internet and "a smart phone with internet connection" has no influence on online education readiness. In general, the online education readiness literature seems to support the present study concerning computer ownership and internet access findings, despite support for the latter being less strong. To interpret the results, there are some prerequisites for online education that need to be met before embarking on it. As found in the present study, ownership of a personal computer and an internet connection at home are clearly two of them.

In this study, it was revealed that computer major university students are readier to online education compared to non-computer major students. Students with computing majors were predominantly comprised of CEIT (Computer Education and Instructional Technology) students in the current study. It is interesting to compare the results of this study with Yurdugul and Demir's (2017) results. Unlike this study, they recruited prospective teachers only. Likewise, they concluded as a result of a cluster analysis, that students majoring at the department of CEIT are readier than those in other departments. Similarly, Alsancak-Sirakaya and Yurdugul (2016) concluded that students in the department of CEIT are better than those from the other departments of the Faculty of Education only in terms of the computer/internet self-efficacy level. In contrast, Adnan and Boz-Yaman (2017) reported in the case of engineering students, that computer engineering students were not readier in terms of online education compared to students of other departments of the Faculty of Engineering. In conclusion, students of the CEIT department are found to be ready for online education (Cobanoglu, Uzunboylar, \& Altun, 2017) because the curriculum of the CEIT department includes many technical and pedagogical courses that contain theories and practices about programming as well as online learning. These courses might increase CEIT students' computer and internet self-efficacy levels, which are factors of online education readiness.

The results showed that the grade year at the university does not affect online education readiness levels. The finding of Pala (2018) is in line with those of the current study. In contrast, Yurdugul and Demir (2017) reported that senior university students are readier for online education compared to freshmen. Yilmaz et al. (2019) reached the same conclusion. Likewise, it was revealed by Hung et al. (2010) that seniors are readier for online education than the other grade students, while juniors are readier than sophomores and freshmen. Moreover, Alsancak-Sirakaya and Yurdugul (2016) concluded that only the computer/internet self-efficacy factor of online education readiness is higher in senior students. To sum up, the majority of studies in the literature indicate that the higher the grade year, the readier students are for online education. The related literature diverges from the findings of the present study, possibly due to the fact that the present study collected data from a wide variety of universities and departments. In fact, other studies in the literature collected data from either only Faculties of Education or just a few departments/universities, limiting the 
generalization of their findings substantially. To speculate about the findings of the current study, the year difference between grade levels appears to be too small for a significant difference to occur. Indeed, there is only a three-year difference in the case of comparing freshmen with seniors, without even mentioning the only one-year difference between successive grade years.

It was found in the current study that as daily internet usage increases; the online education readiness of university students also increases. Coskun et al. (2018) reached a similar conclusion. However, they measured "internet usage for academic purposes". Moreover, Alsancak-Sirakaya and Yurdugul (2016) found that pre-service students whose daily internet usage level is higher, are readier for online education compared to those students using the internet less, only in terms of the computer/internet self-efficacy factor of online education readiness. This is actually an expected result simply because students are likely to learn about basic online tools, services, operations, etc. while using the internet, substantially enhancing their computer and internet self-efficacy levels.

Another finding of this study is that male students are readier than female students. This finding is in line with the findings of online education readiness studies in the literature conducted with students in a Faculty of Medicine (Coskun et al., 2018), Tourism-related department students with no prior online education experience (Olcay, Dos, Surme, \& Duzgun, 2018), and an entire sample of university students (Yilmaz et al., 2019). In contrast, there are many studies in the literature revealing that gender has no effect on online education readiness (Adnan \& Boz-Yaman, 2017; Hung et al., 2010; Pala, 2018). Besides, Sakal (2017) reported no gender-wise difference in three online education readiness factors out of four, except for the online communication self-efficacy factor which was found to be higher in the case of male students. In addition, Alsancak-Sirakaya and Yurdugul (2016) found that two online education readiness factors differed by gender, while the remaining three factors were found not to differ. They found that male students show higher levels of computer/internet self-efficacy, whereas females show higher levels of self-directed learning. In brief, findings as to whether gender has an impact on the online education readiness of university students seems to be far from being clear. These conflicting results are likely to stem from the use of quite different study groups. As another independent variable of the present study, the amount of online education experience was found to affect the online education readiness in favor of experienced university students. However, a study conducted with engineering students by Adnan and Boz-Yaman (2017) yielded a dissimilar result. To interpret the result of the present study, it seems to matter how many online courses students have taken. In fact, students might be getting used to online education process by gaining experience. It was determined in the present study that male university students are readier for online education than females in all levels of online education experience. In the same manner, Basol et al. (2018) reported as a result of hierarchical linear regression analysis that "previous web-based course familiarity" predicted online education readiness of male military vocational college students.

\section{CONCLUSION AND IMPLICATIONS}

This study aimed to address the online education readiness of university students in order to come up with ways of increasing their online education readiness levels, which, in turn, would enhance the quality of their acquisition of learning from the online education experience. This is significant because they are forced by the COVID-19 pandemic to participate in online courses, irrespective of their being ready for them. A survey involving 428 undergraduate students from various universities and departments was carried out with this purpose.

This study highlights the crucial importance of infrastructure such as computer ownership, internet access at home, etc. for the success of online education. The digital gap between undergraduate students can cause serious problems such as inequality of opportunity, thereby severely decreasing the effectiveness and feasibility of online education. To illustrate the point, as many students do not have a personal computer (36.7\%), but nearly all have a smartphone, they use their smartphones for online education activities, making the line between online and mobile learning vague. This high rate of smartphone usage in online education dramatically hampers interaction possibilities during synchronous online lectures and assignment preparation owing to its limited functionality. These adverse aspects of using smartphones appear to be even more serious when the fact that most university students cannot afford to purchase sufficient mobile internet 
packages necessary for the online education process. Since students have a limited amount of mobile internet package, faculty members might feel an obligation to shorten lesson times so as not to cause students to run out of internet packages, if not completely abandon synchronous lessons. In addition, some of them might allow students to turn their cameras off during synchronous lessons. More importantly, they might prefer not to use educational videos or other interactive materials in order to preserve mobile data packages. In summary, interaction, which is one of the most serious concerns in online education, seems to be the very first thing to be detrimentally affected by the lack of infrastructure, substantially hampering the quality of the online education process.

Based on the current study's findings, some suggestions could be made for researchers planning to conduct further studies into online education readiness. First of all, as motivation towards online education was the lowest factor of all $(M=3.37)$, it is recommended that in future studies, researchers should focus on the reason for this low level, as well as the ways to increase this aspect. Furthermore, the mobile learning readiness of university students might be studied in future owing to the fact that a considerable number of university students do not have personal computers, so they try to continue online education using their smartphones (Ekici, 2018). Besides, online education readiness is not just a phenomenon that can be examined exclusively in terms of the learner, so the possibilities of organization, teacher, learner, technological infrastructure, and other factors (peer and family support) should also be taken into consideration in further studies. In addition, the pandemic period, in which individuals' average daily time spent in the online environment increases, might alter students' online communication skills. Therefore, it is highly recommended that researchers examine any differences that might occur in terms of the readiness structures for online education after this transition process. Finally, it is seen that studies on the components of online education readiness have been mostly developed based on the literature. This may make them obsolete due to rapidly-changing online education needs and technologies. Therefore, authentic online education studies focusing on course design, enhancement of interaction, and e-content development can contribute to up-to-date developments and fostering the quality of the online education processes.

Policymakers can also benefit from the findings of the current study. Online education was seen as a bandaid process in dealing with the pandemic, but has the potential to be a medication in terms of some serious educational problems such as cost, inaccessibility, etc. Since it seems that online learning will gain even more importance in the education system, students should be well prepared for it beforehand to get the best out of it. This can be achieved with a selective (preferably mandatory) online learning course taught in every undergraduate program. In this way, higher education institutions and their students might be more prepared to face an imminent second rush to online education. In fact, such a course already exists in the curriculum of the department of CEIT. This course can set an example for possible similar courses in the other departments. As for the lack of computer and internet connection, higher education institutions should provide computer laboratories equipped with fundamental hardware, software, services, etc. required for the online education process, available to those students without access to ICT tools and services. Regarding suggestions for educators, it is strongly advised that they focus on instructional design processes in the web environment, adapt their content to online environments, and reorganize their pedagogy by considering the opportunities and limitations associated with online education technologies.

Authors' Note: The data will only be made available in response to a reasonable request. Data requests may be sent to the corresponding author. There has been no financial support for this work. The authors declare that there is no conflict of interest associated with this publication. All authors contributed equally to this work. Author names are listed in alphabetical order. 


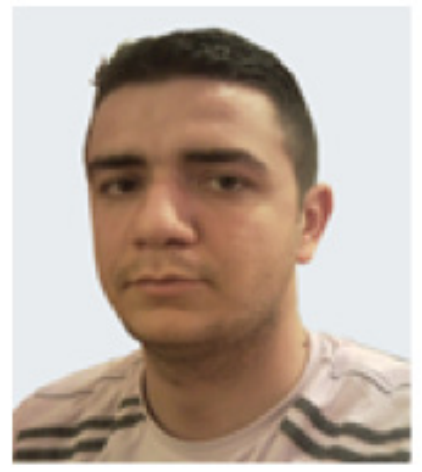

Dr. Murat CINAR is an information technology teacher at the Republic of Turkey Ministry of National Education. He received his Ph.D. degree in Computer Education and Instructional Technology from Hacettepe University in 2019. His research interests include human-computer interaction, technology use in schools, computational thinking, programming education, and web-based course design.

\section{Murat CINAR}

Address: Borsa Istanbul Vocational and Technical Anatolian High School, Republic of Turkey Ministry of National Education, 01260, Adana, Turkey

Phone: +90322346 4471

E-mail: murat_cinar@rocketmail.com; muratcinar@hacettepe.edu.tr

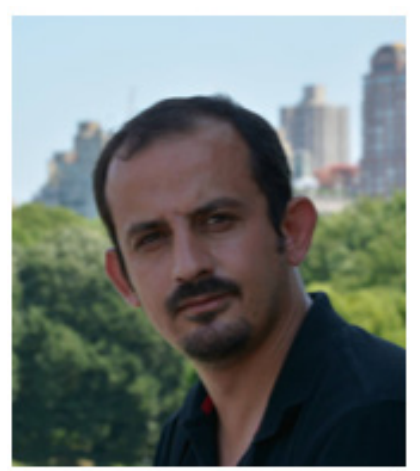

Dr. Murat EKICI is a faculty member at Usak University Faculty of Education. He received his Ph.D. degree in Computer Education and Instructional Technology from Hacettepe University in 2018. His research interests include mobile learning, technology integration, human-computer interaction, design and development of constructivist learning environments and artificial intelligence in education.

\section{Murat EKICI}

The Department of Computer Education and Instructional Technology

Address: Faculty of Education, Usak University 1 Eylul Campus, 64200, Usak, Turkey.

Phone: +902762212130

E-mail: muratekici83@gmail.com; murat.ekici@usak.edu.tr

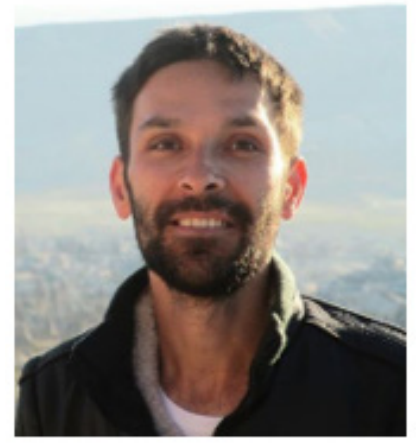

Dr. Omer DEMIR is a research assistant at the Department of Computer Education and Instructional Technology (CEIT) of Faculty of Education at Hakkari University in Hakkari, Turkey. He received his doctoral degree at the department of CEIT at Hacettepe University in Ankara, Turkey, in 2019. Omer Demir is professionally interested in studying game-based learning, computational thinking, coding education, pair programming, self-directed learning, e-learning readiness, e-learning course design and scale developments and adaptations.

\section{Omer DEMIR}

The Department of Computer Education and Instructional Technology,

Address: Faculty of Education, Hakkari University, Hakkari, Turkey.

Phone: +90 $4382121211 / 12$

E-mail: omerdemir1986@gmail.com; omerdemir@hakkari.edu.tr 


\section{REFERENCES}

Adnan, M. \& Boz-Yaman, B. (2017). Profile of engineering undergraduates on readiness and satisfaction for e-learning. Turkish Journal of Computer and Mathematics Education, 8(2), 218-243. doi:10.16949/ turkbilmat.280165.

Akaslan, D. \& Law, E. L. C. (2011a). Measuring student e-learning readiness: A case about the subject of electricity in higher education institutions in Turkey. In H. Leung, E. Popescu, Y. Cao, R. W. H. Lau, \& W. Nejdl (Eds.), Advances in Web-Based Learning (ICWL 2011) (pp. 209-218). Berlin, Heidelberg, Germany: Springer Press.

Akaslan, D., \& Law, E. L. C. (2011b, 4-6 April). Measuring teachers' readiness for e-learning in higher education institutions associated with the subject of electricity in Turkey. Paper presented at the 2011 IEEE Global Engineering Education Conference (EDUCON), Amman, Jordan.

Alsancak-Sirakaya, D. \& Yurdugul, H. (2016). Investigation of online learning readiness level of teacher candidates: The sample of Ahi Evran University. Journal of Kirsehir Education Faculty, 17(1), 185200.

Asaari, M. H. A. H., \& Karia, N. (2005). Adult learners and e-learning readiness: A case study. Paper presented at the European College Teaching \& Learning Conference, Athens, Greece.

Basol, G., Cigdem, H., \& Unver, T. K. (2018). Variables explaining the online learning readiness level of students: Turkish vocational college example. European Journal of Education Studies, 4(10), 14-32. doi:10.5281/zenodo.1302956.

Batane, T. (2010). Rapid prototyping for designing and delivering technology-based lessons. In M. Orey, S. A. Jones, \& R. M. Branch (Eds.), Educational Media and Technology Yearbook (pp. 45-55). Boston, MA, USA: Springer Press.

Bates, A. W. (2005). Technology, e-learning and distance education (2 ${ }^{\text {nd }}$ ed.). Abingdon, Oxon, UK: Routledge Press.

Bernard, R. M., Brauer, A., Abrami, P. C., \& Surkes, M. (2004). The development of a questionnaire for predicting online learning achievement. Distance Education, 25(1), 31-47. doi:10.1080/0158791 042000212440 .

Bilgic, H. G., \& Tuzun, H. (2020). Issues and challenges with web-based distance education programs in Turkish higher education institutes. Turkish Online Journal of Distance Education, 21(1), 143-164. doi:10.17718/tojde.690385.

Boling, E. C., Hough, M., Krinsky, H., Saleem, H., \& Stevens, M. (2012). Cutting the distance in distance education: Perspectives on what promotes positive, online learning experiences. The Internet and Higher Education, 15(2), 118-126. doi:10.1016/j.iheduc.2011.11.006.

Chang, V. (2016). Review and discussion: E-learning for academia and industry. International Journal of Information Management, 36(3), 476-485. doi:10.1016/j.ijinfomgt.2015.12.007.

Chen, S. J. (2007). Instructional design strategies for intensive online courses: An objectivist-constructivist blended approach. Journal of Interactive Online Learning, 6(1), 72-86.

Cohen, J. (1988). Statistical power analysis for the behavioral sciences ( $2^{\text {nd }}$ ed.). Hillsdale, NJ, USA: Lawrence Erlbaum Press.

Coskun, O., Ozeke, V., Budakoglu, I., \& Kula, S. (2018). E-learning readiness of Turkish medical students: A sample from Gazi University. Gazi Medical Journal, 29(4), 340-345. doi:10.12996/gmj.2018.91.

Creswell, J. W. (2012). Educational research: Planning, conducting, and evaluating quantitative and qualitative research ( $4^{\text {th }}$ ed.). Boston, MA, USA: Pearson Press.

Cobanoglu, A. A., Uzunboylar, O., \& Altun, E. (2017). Investigating on-line learning readiness, attitudes and perceived on-line sociability in a collaborative blended course. Electronic Journal of Social Sciences, 16(63), 1218-1122. doi:10.17755/esosder.292310. 
Darab, B. \& Montazer, G. A. (2011). An eclectic model for assessing e-learning readiness in the Iranian universities. Computers \& Education, 56(3), 900-910. doi:10.1016/j.compedu.2010.11.002.

Davis, F. D. (1989). Perceived usefulness, perceived ease of use, and user acceptance of information technology. MIS Quarterly, 13(3), 319-340. doi:10.2307/249008.

Demir, O. \& Yurdugul, H. (2013). Self-directed learning with technology scale for young students: A validation study. International Journal of Educational Research, 4(3), 58-73.

Demir, O. \& Yurdugul, H. (2015). The exploration of models regarding e-learning readiness: Reference model suggestions. International Journal of Progressive Education, 11(1), 173-194.

Dray, B. J., Lowenthal, P. R., Miszkiewicz, M. J., Ruiz-Primo, M. A., \& Marczynski, K. (2011). Developing an instrument to assess student readiness for online learning: a validation study. Distance Education, 32(1), 29-47. doi:10.1080/01587919.2011.565496.

Ekici, M. (2018). The investigation of the effects of mobile technology based learning applications on scientific thinking process. (Unpublished doctoral dissertation). Hacettepe University, Ankara, Turkey.

Garrison, D. R. (1997). Self-directed learning: Toward a comprehensive model. Adult education quarterly, 48(1), 18-33. doi:10.1177/074171369704800103.

Hartnett, M., St. George, A., \& Dron, J. (2011). Examining motivation in online distance learning environments: Complex, multifaceted and situation-dependent. The International Review of Research in Open and Distributed Learning, 12(6), 20-38. doi: 10.19173/irrodl.v12i6.1030.

Hung, M. L., Chou, C., Chen, C. H., \& Own, Z. Y. (2010). Learner readiness for online learning: Scale development and student perceptions. Computers \& Education, 55(3), 1080-1090. doi:10.1016/j. compedu.2010.05.004.

Ilgaz, H. \& Gulbahar, Y. (2015). A snapshot of online learners: e-Readiness, e-Satisfaction and expectations. The International Review of Research in Open and Distributed Learning, 16(2). doi:10.19173/irrodl. v16i2.2117.

Joosten, T. \& Cusatis, R. (2020). Online learning readiness. American Journal of Distance Education, 34(3), 180-193. doi:10.1080/08923647.2020.1726167.

Kabatas, S. (2019). Evaluation of teacher candidates' perceptions of digital citizenship in terms of lifelong learning attitudes. (Unpublished master's thesis). Bartin University, Bartin, Turkey.

Knowles, M. S. (1975). Self-directed learning: A guide for learners and teachers. NY, USA: Association Press.

Kwak, S. G. \& Kim, J. H. (2017). Central limit theorem: the cornerstone of modern statistics. Korean journal of anesthesiology, 70(2), 144-156. doi: 10.4097/kjae.2017.70.2.144.

Law, K. M. Y., Lee, V. C. S., \& Yu, Y. T. (2010). Learning motivation in e-learning facilitated computer programming courses. Computers \& Education, 55(1), 218-228. doi:10.1016/j. compedu.2010.01.007.

Mayer, R. E. (2017). Using multimedia for e-learning. Journal of Computer Assisted Learning, 33(5), 403423. doi:10.1111/jcal.12197.

McCutcheon, K., Lohan, M., Traynor, M., \& Martin, D. (2015). A systematic review evaluating the impact of online or blended learning vs. face-to-face learning of clinical skills in undergraduate nurse education. Journal Advanced Nursing, 71(2), 255-270. doi:10.1111/jan.12509.

McVay, M. (2000). How to be a successful distance learning student: Learning on the internet ( $2^{\text {nd }}$ ed.). NY, USA: Prentice Hall.

Mercer, N. \& Howe, C. (2012). Explaining the dialogic processes of teaching and learning: The value and potential of sociocultural theory. Learning, Culture and Social Interaction, 1(1), 12-21. doi:10.1016/j.lcsi.2012.03.001.

Moore, J. L., Dickson-Deane, C., \& Galyen, K. (2011). E-Learning, online learning, and distance learning environments: Are they the same? The Internet and Higher Education, 14(2), 129-135. doi:10.1016/j.iheduc.2010.10.001. 
Olcay, A., Dos, B., Surme, M., \& Duzgun, M. (2018). A study on determining the readiness of students who receive tourism education for electronic learning. Kastamonu Education Journal, 26(2), 427438. doi:10.24106/kefdergi.389940.

Omoda-Onyait, G. \& Lubega, J. T. (2011). E-learning readiness assessment model: A case study of higher institutions of learning in Uganda. In R. Kwan, J. Fong, L. F. Kwok, \& J. Lam (Eds.), Hybrid Learning. $4^{\text {th }}$ International Conference on Hybrid Learning (ICHL 2011) (pp. 200-211). Berlin, Heidelberg, Germany: Springer Press.

Pala, K. (2018). A research on determining the readiness levels of e-learning students in vocational tourism education. (Unpublished master's thesis). Gazi University, Ankara, Turkey.

Parkes, M., Stein, S., \& Reading, C. (2015). Student preparedness for university e-learning environments. The Internet and Higher Education, 25, 1-10. doi:10.1016/j.iheduc.2014.10.002.

Sakal, M. (2017). Investigation on the demographic characteristics of readiness levels of online educated students. Journal of Social Sciences and Humanities Researches, 18(39), 81-102.

Simonson, M., Schlosser, C., \& Orellana, A. (2011). Distance education research: a review of the literature. Journal of Computing in Higher Education, 23, 124-142. doi: 10.1007/s12528-011-9045-8.

Smith, P.J., Murphy, K. L., \& Mahoney, S. E. (2003). Towards identifying factors underlying readiness for online learning: An exploratory study. Distance Education, 24(1), 57-67. doi:10.1080/01587910303043.

Soydal, I., Alir, G., \& Unal, Y. (2011). Are Turkish universities ready for e-learning: A case of Hacettepe University Faculty of Letters. Information Services and Use, 31(3-4), 281-291. doi:10.3233/ISU2012-0659.

Stodberg, U. (2012). A research review of e-assessment. Assessment \& Evaluation in Higher Education, 37(5), 591-604. doi:10.1080/02602938.2011.557496.

Sun, P. C., Tsai, R. J., Finger, G., Chen, Y. Y., \& Yeh, D. (2008). What drives a successful e-Learning? An empirical investigation of the critical factors influencing learner satisfaction. Computers \& Education, 50(4), 1183-1202. doi:10.1016/j.compedu.2006.11.007.

Tubaishat, A. \& Lansari, A. (2011). Are students ready to adopt e-learning? A preliminary e-readiness study of a university in the Gulf Region. International Journal of Information and Communication Technology Research, 1(5), 210-215.

Tuzun, H. \& Cinar, M. (2016). Guidelines for transferring residential courses into web. The International Review of Research in Open and Distributed Learning, 17(4). doi:10.19173/irrodl.v17i4.2323.

United Nations Educational Scientific and Cultural Organization (UNESCO). (2020). COVID-19: A global crisis for teaching and learning. Retrieved from https://unesdoc.unesco.org/ark:/48223/ pf0000373233.locale=en.

Unal, Y., Alir, G., \& Soydal, I. (2014). Students readiness for e-learning: An assessment on Hacettepe University department of information management. In J. N. Gathegi, Y. Tonta, S. Kurbanoglu, U. $\mathrm{Al}, \& \mathrm{Z}$. Taskin (Eds.), Challenges of Information Management Beyond the Cloud. $4^{\text {th }}$ International Symposium on Information Management in a Changing World (IMCW 2013) (pp. 137-147). Berlin, Heidelberg, Germany: Springer Press.

Vygotsky, L. S. (1978). Mind in society. Cambridge, MA, USA: Harvard University Press.

Yilmaz, R., Sezer, B., \& Yurdugul, H. (2019). Investigation of university students e-learning readiness: Example of Bartin University. Ege Journal of Education, 20(1), 180-195. doi:10.12984/ egeefd.424614.

Yurdugul, H. \& Demir, O. (2017). An investigation of pre-service teachers' readiness for e-learning at undergraduate level teacher training programs: The case of Hacettepe University. Hacettepe University Journal of Education, 32(4), 896-915. doi:10.16986/huje.2016022763.

Zhu, M., Bonk, C. J., \& Doo, M. Y. (2020). Self-directed learning in MOOCs: exploring the relationships among motivation, self-monitoring, and self-management. Educational Technology Research and Development. doi:10.1007/s11423-020-09747-8. 